\title{
Effects of tarragon (Artemisia dracunculus) powder on broiler performance parameters and histopathology of internal organs
}

\author{
Muhammet Ali Tunça ${ }^{a^{*}}$, Serkan Yıldırım ${ }^{\mathrm{b}}$, Mehmet Akif Yörük
}

\begin{abstract}
The aim of this study is to evaluate whether the addition of tarragon in the diet of broiler chickens affects their performance and histological structures of internal organs. A total of 240 day-old Ross 308 male broiler chickens were used. The experiment included four treatment groups, with six replications per treatment. The experiment lasted 42 days and the chickens were provided with feed and water ad libitum. Experimental groups were given basal diet only (control group), basal diet $+0.1 \%$ tarragon powder (T1 group), basal diet $+0.2 \%$ tarragon powder (T2 group) and basal diet $+0.5 \%$ tarragon powder (T3 group). The tarragon additive did not affect the values of the daily feed intake (DFI) and feed conversion rate (FCR) during the trial periods, while the highest daily weight gain (DWG) was recorded in the control group $(P<0.05)$ on days $29-35$ and 36-42. The longest jejunum villi was observed in the $\mathrm{T} 2$ group $(P<0.05)$. The results indicate that different amounts of tarragon powder additive did not affect the DFI and FCR as performance parameters, while they had a negative impact on DWG. In addition, the livers, kidneys and intestinal tissue structures did not change. Therefore, the tarragon powder had no negative effects on the health of chickens.

Key words: blood, broiler, histopathology, tarragon, villus.
\end{abstract}

\section{INTRODUCTION}

Feed additives have been defined as substances safely added to animal feed to accelerate their development, increasing both the quality and quantity of the products, without negatively affecting the health of those animals (Yavuz 2001). The use of feed additives is an important strategy for enhancing livestock performance and health. Many organic and inorganic substances have been used as feed additives. For example, antibiotics have been added to provide antimicrobial effects and to increase the feed conversion rate (Church and Pont 1988), but the use of antibiotics as a yield-enhancing feed additive is prohibited because of their possible risks to human health (Newman 2002).

In this sense, the use of aromatic plants as natural feed additives, providing both nutritional and medical features, has gained importance (Pereira et al 2015). Tarragon, for example, is often cited for its therapeutic and anti-inflammatory properties which protect against certain infections and liver disease. Tarragon belongs to the genus Artemisia, which include about 500 species, with different aromatic flavours and different biological properties (Nurzy ĚskaWierdak and ZawiĞlak 2014). One of the most significant of these species is Artemisia dracunculus (Karimia et al 2015), which can be found on the steppes of Mongolia

Received: 16.05 .2019

Accepted: 05.08.2019.

a Department of Animal Science, Ataturk University Vocational High School of Narman, Narman, Turkey.

${ }^{b}$ Department of Pathology, Veterinary Faculty, Ataturk University, Erzurum, Turkey.

cDepartment of Animal Nutrition and Nutritional Disorders, Veterinary Faculty, Ataturk University, Erzurum, Turkey.

*Corresponding author: MA Tunç; matunc@atauni.edu.tr and Siberia (Aglarova et al 2008). In Anatolia, Turkey, it is known as "Tarhun" (Kordali et al 2005').

The essential oils found in tarragon contain phenolic compounds, carotenoids, coumarin compounds, tannins, polyacetylene, sesquiterpene, and mineral compounds. In addition, tarragon has unique biological activity and phytochemicals (Daly et al 2010, Obolskiy et al 2011, Tak et al 2014, Kumlay et al 2015). Tarragon is known to have antibacterial, antifungal, and antitumor properties and has been used in antidiarrheal, analgesic and anti-inflammatory treatments (Obolskiy et al 2011, Meepagala et al 2002, Kordali et al 2005a , Lopes-Lutz et al 2008, Jalilzadeh-Amin and Qarehdarvishlu 2014, Eidi et al 2015). For example, due to its level of terpene, tarragon has been used to treat gastrointestinal complaints, such as diarrhoea (Kumlay et al 2015, Jalilzadeh-Amin and Maham 2015). There are a few studies about the use of tarragon as a feed additive in poultry nutrition (Yildirim and Tunç 2018, Gharetappe et al 2015, Sen et al 2012, Incharoen et al 2009), but this study provides more extensive research in terms of nutrients and health. The purpose of this study is to investigate the effect of tarragon powder on performance and histological changes of organs in broiler chickens.

\section{MATERIAL AND METHODS}

This study was performed in accordance with the guidelines approved by the Local Ethics Council of Animal Experiments at Ataturk University (Protocol Number 20/2014).

\section{EXPERIMENTAL BIRDS, DESIGN, PLANT AND TREATMENTS}

Two hundred and forty one day old male commercial Ross 308 broiler chickens were used in this study. The chickens were divided into four dietary treatment groups 
with six replications per treatment. The chickens were provided feed and water ad libitum until the end of the experiment. In the study, iron floored cages of 150 x $200 \mathrm{~cm}$ were used. The diet was prepared according to the standard diets for male Ross 308 chickens; table 1 shows the dietary components for all stages of breeding. The commercial diet was used in this experiment. Tarragon additive was mixed homogeneously into the feed mixers of the commercial feed mill. The experimental groups were fed as follows: the control group was only fed the basal diet, group T1 was fed the basal diet $+0.1 \%$ tarragon powder, group T2 was fed the basal diet $+0.2 \%$ tarragon powder and group T3 was fed the basal diet $+0.5 \%$ tarragon powder.

The tarragon powder used in this study came from plants obtained from the region of Erzurum in Eastern Turkey. After the cleaning and removal of the unusable parts, the plants were dried at ambient temperature. The tarragon was then converted into powder and added to the experimental diets. Tarragon doses were determined with reference to other studies.

\section{EVALUATED CHARACTERISTICS}

Performance. The data for performance parameters were collected weekly and calculated daily. During the study, chickens in all cages were weighed every week, and the average live weight gain was calculated. The average feed consumption of the chickens was calculated by weighing the feed in the cages every week. The feed conversion rate was calculated by dividing the average feed intake by the average live weight gain (feed conversion rate = daily feed intake $\div$ daily weight gain). At the end of the experiment, the chickens were slaughtered.

Histopathology examination. At the end of the study, the livers, kidneys and intestines were taken from 30 animals from each group. Liver, kidney and jejunum tissues were immediately excised for histological examination and immersed in $10 \%$ neutral formalin solution for stabilisation. Sections were taken from the diaphragmatic lobe of the livers, from the same region of the kidneys and from the ileum of the intestines for examination. Biopsies were embedded in paraffin, and then sectioned and stained with hematoxylin and eosin $(\mathrm{H} \& \mathrm{E})$. All tissues were examined both microscopically and with ZEN imaging software.

\section{STATISTICAL ANALYSIS}

Data were expressed as mean $(\mathrm{M}) \pm$ standard deviation (SD). A statistical package for the SPSS system was used to analyse the data with the GLM procedure. Group effects were tested first, and then post-hoc Tukey's tests were used to compare the group differences. A $P<0.05$ was considered the lowest level of significance.

Table 1. Composition of the experimental diets (\%).

\begin{tabular}{|c|c|c|c|}
\hline Feeds Ingredients & $\begin{array}{l}\text { Starting } \\
(1-14 \mathrm{~d})\end{array}$ & $\begin{array}{l}\text { Growing } \\
(15-35 \mathrm{~d})\end{array}$ & $\begin{array}{l}\text { Finishing } \\
(36-42 \mathrm{~d})\end{array}$ \\
\hline Corn & 43.41 & 40.13 & 38 \\
\hline Soybean meal (\%48) & 34.4 & 26.5 & 20.5 \\
\hline Wheat & 15.25 & 25.28 & 32.11 \\
\hline Vegetable oil & 2 & 3.5 & 4.8 \\
\hline Dicalcium phosphate & 2.3 & 2 & 2 \\
\hline DL-methionine & 0.2 & 0.22 & 0.24 \\
\hline Lysine hydrochloride & 0.27 & 0.22 & 0.2 \\
\hline Limestone & 0.87 & 0.85 & 0.85 \\
\hline Salt & 0.3 & 0.3 & 0.3 \\
\hline Mineral and Vitamin Premix & 1 & 1 & 1 \\
\hline \multicolumn{4}{|c|}{ Nutritional composition ( $\%$ of the diet) } \\
\hline $\mathrm{ME}(\mathrm{kcal} / \mathrm{kg})$ & 2930 & 3110 & 3220 \\
\hline Crude protein & 22.5 & 20 & 18 \\
\hline Crude fiber & 3.15 & 3.5 & 3.7 \\
\hline Calcium & 0.97 & 0.86 & 0.85 \\
\hline Available phosphorus & 0.51 & 0.48 & 0.47 \\
\hline Lysine & 1.45 & 1.30 & 1.22 \\
\hline Methionine & 0.52 & 0.50 & 0.48 \\
\hline Methionine + cysteine & 0.90 & 0.81 & 0.73 \\
\hline
\end{tabular}

Supplied per kilogram of diet 10,000 IU vitamin A, $12 \mathrm{mg}$ vitamin E, $2000 \mathrm{IU}$ vitamin D, $36 \mathrm{mg}$ niacin, $10 \mathrm{mg}$ D-pantothenic acid, $3.61 \mathrm{mg}$ riboflavin, $3.52 \mathrm{mg}$ pyridoxine, $2.41 \mathrm{mg}$ thiamine, $1.39 \mathrm{mg}$ folic acid, $0.16 \mathrm{mg}$ biotin and $0.03 \mathrm{mg}$ vitamin $\mathrm{B}, 59 \mathrm{mg}$ manganese, $41 \mathrm{mg}$ zinc, $1281 \mathrm{mg}$ iron, 7,9 $\mathrm{mg}$ copper, $0.31 \mathrm{mg}$ iodine and $0.22 \mathrm{mg}$ selenium. 


\section{RESULTS}

In this study, we evaluated the effect of adding three different levels of tarragon to standard chicken feed on the performance of the chickens and the histological appearance of their internal organs. The greatest weight gains were observed in the control group on days 29-35 and days $36-42$, whereas the lowest gain $(P<0.05)$ was observed in the T3 group. Weights for the T1 and T2 groups were similar to those of the T3 group. A significant difference among the groups and periods was not observed for daily feed intake and the feed conversion rate (table 2). In this study, the longest jejunum villi was observed in the T2 group $(P<0.05$; table 3$)$.

In this study, no changes were observed in the appearance of the liver, kidney and intestinal tissues obtained from the experimental groups (figures 1, 2 and 3).

\section{DISCUSSION}

\section{PERFORMANCE PARAMETERS}

Another study added peppermint and tarragon to the broiler diets, and the effect of the tarragon additive was not significant on average body weight $(\mathrm{ABW})$, average daily gain (ADG) or feed conversion rate (FCR). The feed intake only increased during days 0-4 (Gharetappe et al 2015). It is thought that the use of the terpenes in these plants on chickens becomes useless, and they may be trapped in plant secretory glands due to the rapid passage times in the digestive system (Dorman and Deans 2000).

In similar studies, it was found that adding tarragon to the chicken feed in different amounts did not influence the food consumption rate, and that the highest rate of feed utilisation (for days 1-21 and days 1-42) also took place in the group receiving the $0.5 \%$ tarragon portion. At the same time, the lowest $(P<0.05)$ mean body weights of the chickens were noticed in the group receiving a $0.5 \%$ portion of tarragon during days 1-42, when there was no significant difference between the control group and the group receiving $0.125 \%$ of tarragon in days $1-21$ (Hosseinzadeh et al 2014). The addition of a 5\% tarragon mix appears to have a negative effect on mean body weight and on the FCR (Hosseinzadeh and Moghaddam 2014). During the tarragon drying process, it is possible to destroy all the useful combinations making them lose their effectiveness (Arabhosseini et al 2007).

Table 2. Effect tarragon additive performance values of broilers $(M \pm S D)$.

\begin{tabular}{|c|c|c|c|c|c|}
\hline \multirow{3}{*}{ Treatment } & Starting & \multicolumn{2}{|c|}{ Growing } & \multicolumn{2}{|c|}{ Finishing } \\
\hline & \multicolumn{5}{|c|}{ Days } \\
\hline & $7-14$ & $15-21$ & $22-28$ & $29-35$ & $36-42$ \\
\hline \multicolumn{6}{|c|}{ Daily feed intake (g) } \\
\hline $\mathrm{C}$ & $67.09 \pm 1.73$ & $113.54 \pm 3.95$ & $180.65 \pm 4.10$ & $191.10 \pm 7.07$ & $178.58 \pm 11.02$ \\
\hline $\mathrm{T} 1$ & $65.43 \pm 1.13$ & $112.49 \pm 1.59$ & $181.42 \pm 2.85$ & $178.94 \pm 14.71$ & $170.85 \pm 11.98$ \\
\hline $\mathrm{T} 2$ & $65.40 \pm 1.50$ & $114.11 \pm 1.77$ & $181.97 \pm 4.56$ & $179.63 \pm 7.53$ & $172.11 \pm 13.68$ \\
\hline $\mathrm{T} 3$ & $67.87 \pm 2.49$ & $115.33 \pm 3.46$ & $179.82 \pm 8.62$ & $182.06 \pm 3.72$ & $170.63 \pm 11.94$ \\
\hline $\mathrm{p}$ & 0.064 & 0.408 & 0.332 & 0.086 & 0.261 \\
\hline \multicolumn{6}{|c|}{ Daily weight gain (g) } \\
\hline $\mathrm{C}$ & $33.20 \pm 2.39$ & $61.34 \pm 5.70$ & $92.61 \pm 8.69$ & $95.15 \pm 5.79^{a}$ & $90.55 \pm 6.53^{\mathrm{a}}$ \\
\hline $\mathrm{T} 1$ & $32.20 \pm 0.69$ & $60.30 \pm 1.54$ & $89.77 \pm 1.66$ & $88.19 \pm 9.63^{b}$ & $84.08 \pm 9.49^{b}$ \\
\hline $\mathrm{T} 2$ & $33.07 \pm 0.67$ & $60.48 \pm 1.43$ & $90.66 \pm 6.30$ & $89.21 \pm 5.84^{b}$ & $85.62 \pm 9.31^{b}$ \\
\hline $\mathrm{T} 3$ & $34.51 \pm 0.71$ & $61.63 \pm 1.04$ & $91.72 \pm 8.06$ & $88.16 \pm 5.91^{\mathrm{b}}$ & $84.04 \pm 4.35^{\mathrm{b}}$ \\
\hline $\mathrm{p}$ & 0.109 & 0.903 & 0.769 & 0.034 & 0.043 \\
\hline \multicolumn{6}{|c|}{ Feed conversion rate } \\
\hline $\mathrm{C}$ & $2.02 \pm 0.14$ & $1.85 \pm 0.13$ & $1.95 \pm 0.20$ & $2.00 \pm 0.06$ & $1.97 \pm 0.11$ \\
\hline $\mathrm{T} 1$ & $2.03 \pm 0.04$ & $1.86 \pm 0.04$ & $2.02 \pm 0.06$ & $2.03 \pm 0.09$ & $2.03 \pm 0.09$ \\
\hline $\mathrm{T} 2$ & $1.98 \pm 0.03$ & $1.89 \pm 0.05$ & $2.02 \pm 0.17$ & $2.01 \pm 0.06$ & $2.01 \pm 0.19$ \\
\hline $\mathrm{T} 3$ & $1.97 \pm 0.06$ & $1.87 \pm 0.08$ & $1.96 \pm 0.16$ & $2.06 \pm 0.14$ & $2.03 \pm 0.14$ \\
\hline $\mathrm{p}$ & 0.142 & 0.498 & 0.902 & 0.106 & 0.893 \\
\hline
\end{tabular}

C (Control group): The basal diet.

T1: The basal diet $+0.1 \%$ tarragon powder

$\mathrm{T} 2$ : The basal diet $+0.2 \%$ tarragon powder.

T3: The basal diet $+0.5 \%$ tarragon powder.

${ }^{\mathrm{a}-\mathrm{c}}$ Means with different superscript within the same column are statistically different $(P<0.05)$. 
Table 3. Jejunum villi lengths $(\mathrm{M} \pm \mathrm{SD})$.

\begin{tabular}{lc}
\hline \multirow{2}{*}{ Treatment } & $0-42$ days \\
\cline { 2 - 2 } & JVL $(\mu \mathrm{m})$ \\
\hline $\mathrm{C}$ & $514.50 \pm 3.00^{\mathrm{b}}$ \\
$\mathrm{T} 1$ & $519.52 \pm 2.30^{\mathrm{ab}}$ \\
$\mathrm{T} 2$ & $523.01 \pm 3.01^{\mathrm{a}}$ \\
$\mathrm{T} 3$ & $516.21 \pm 3.28^{\mathrm{b}}$ \\
$\mathrm{p}$ & 0.043 \\
\hline
\end{tabular}

JVL: Jejunum villi lengths.

$\mathrm{C}$ (Control group): The basal diet.

T1: The basal diet $+0.1 \%$ tarragon powder.

T2: The basal diet $+0.2 \%$ tarragon powder.

T3: The basal diet $+0.5 \%$ tarragon powder.

${ }^{\mathrm{a}-\mathrm{c}}$ Means with different superscript within the same column are statistically different $(P<0.05)$.

The highest $(P<0.05)$ feed intake in a study on Japanese quail was noticed in the group receiving a $1.5 \%$ portion of tarragon and the group treated with antibiotics (control group) in the fifth week. On the other hand, the lowest $(P<0.05)$ feed intake was noticed in the group receiving a $2 \%$ portion of tarragon. The highest $(P<0.05)$ live weight gain and FCR were noticed in the group treated with antibiotics (the control group) in the second and sixth weeks, whereas the lowest $(P<0.05)$ live weight gain was noticed in the group receiving only a $1.5 \%$ portion of tarragon (Angas et al 2015). Tarragon additive results in a reduction in the number of pathogenic bacteria and an increase in the number of beneficial bacteria in the gut, stimulating an increase in the secretion of digestive latex (Ebrahimi 2011). For this reason, performance may have improved performance. In this study, the tarragon additive had a negative effect for days 29-35 and 36-42 in the area of daily weight gain. It is possible that this is due to the bioactive compounds in the structure, the plant drying and its rapid digestion by the birds.

\section{HISTOPATHOLOGY AND LENGTH OF INTESTINAL VILLUS}

Tarragon is thought to have no effect on the pathology of the liver, kidneys, and intestines due to its beneficial effects (Ebrahımı et al 2013). In many nutritional studies, villus length is related to the balance between the increase in the number of intestinal cells, destruction and cell death. In many nutrition studies, villus length has been shown to be a determinant of both nutrient absorption and intestinal health (Uni et al 1998, Laudadio et al 2012, Sen et al 2012, Incharoen et al 2009, Ariyadi and Harimurti 2015). Natural additives improve the structure of epithelial cells in the intestinal mucosa and extend the size of the suction cells (Wang and Peng 2008, Incharoen et al 2010, Fonseca-Garcíaa et al 2017). Therefore, in the experiment, villus length increased in the group where $0.2 \%$ tarragon powder was added to the feed. Olnood et al (2015) stated that additives could support bacterial growth and the development of anatomical structures.

It has been noted that there are different conclusions on the effects of tarragon as a feed additive for poultry, and it is believed that this diversity results from differences in the essential oils, acids, bioactive compounds, and terpene compositions of tarragon plants (Eisenman et al 2013). Differences in the composition of the structure of the plant can influence both the endogenous secretions and the performance values in chickens (Cross et al 2007).
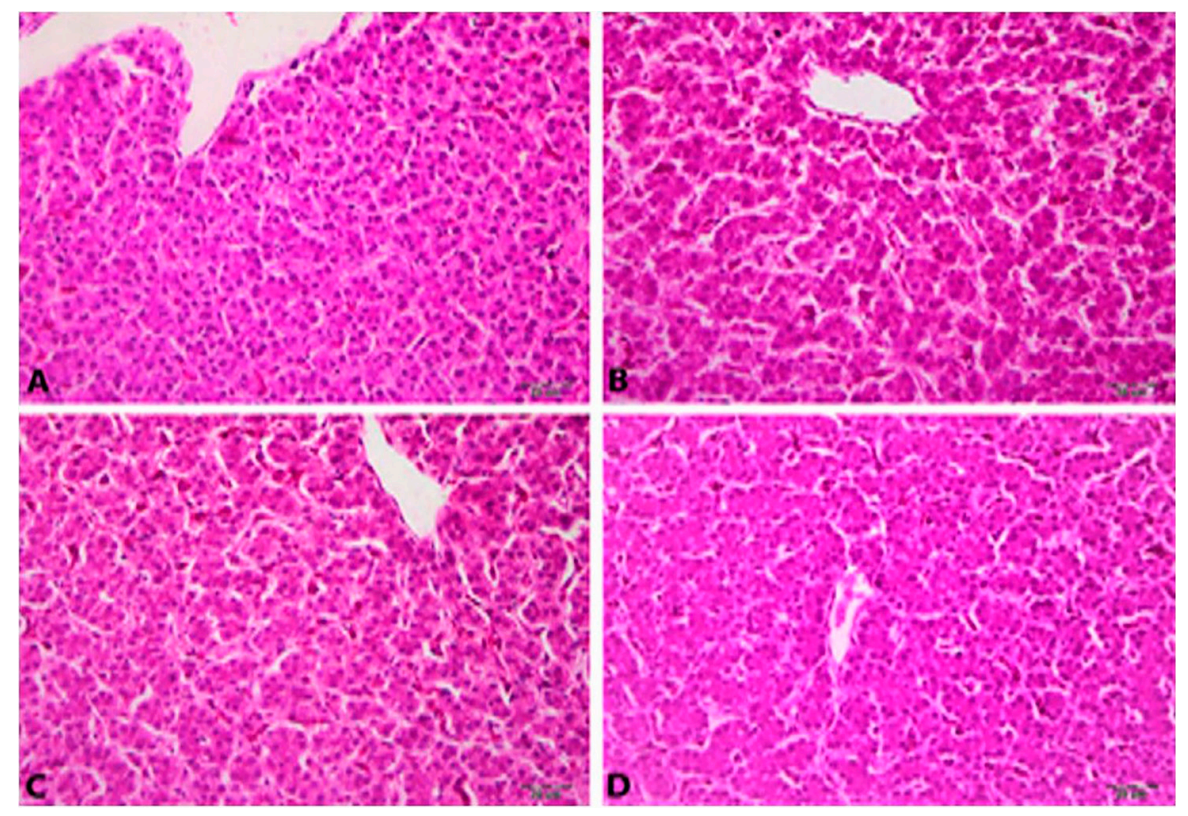

Figure 1. Control group (A); Liver tissues structure normal histological, Group T1 (B); Liver tissues structure normal histological, Group T2 (C); Liver tissues structure normal histological, Group T3 (D); Liver tissues structure normal histological, H\&E, Bar: $20 \mu$ m. 


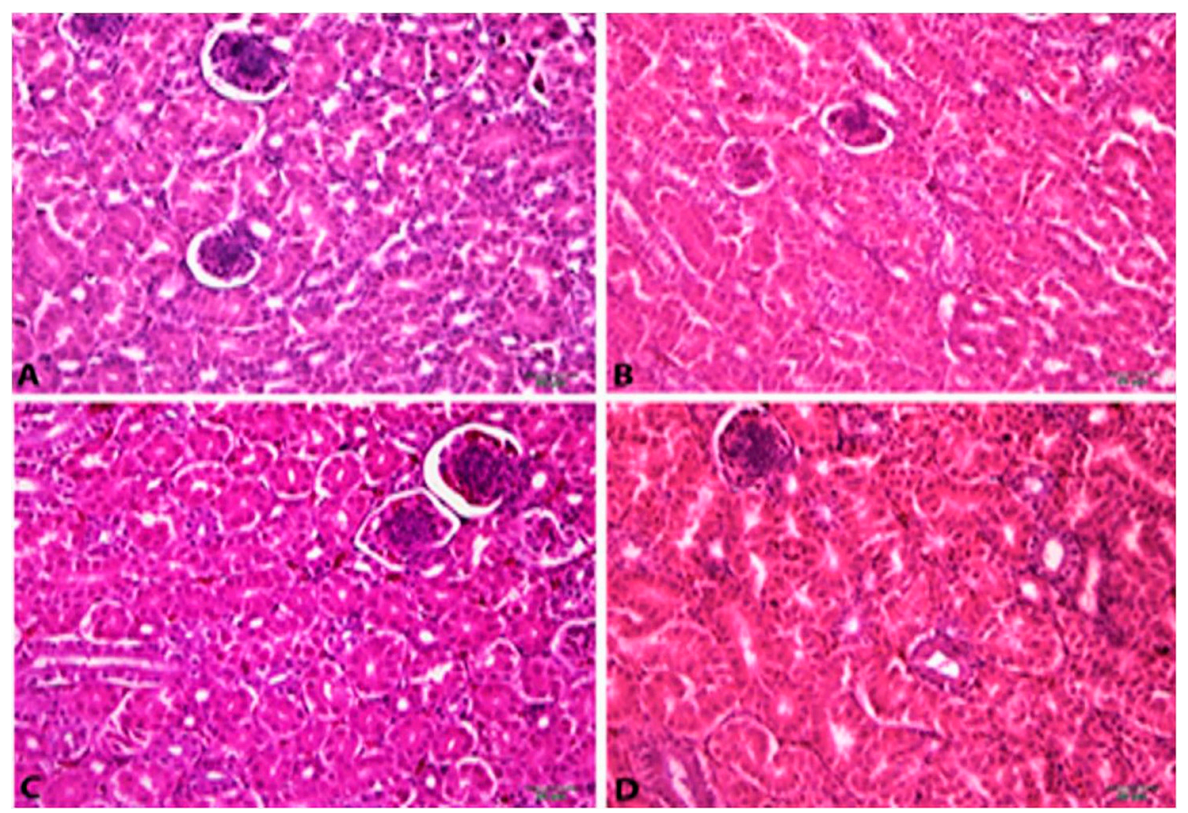

Figure 2. Control group (A); Kidney tissues structure normal histologic, Group T1 (B); Kidney tissues structure normal histologic, Group T2 (C); Kidney tissues structure normal histologic, Group T3 (D); Kidney tissues structure normal histologic, H\&E, Bar: $20 \mu$ m.

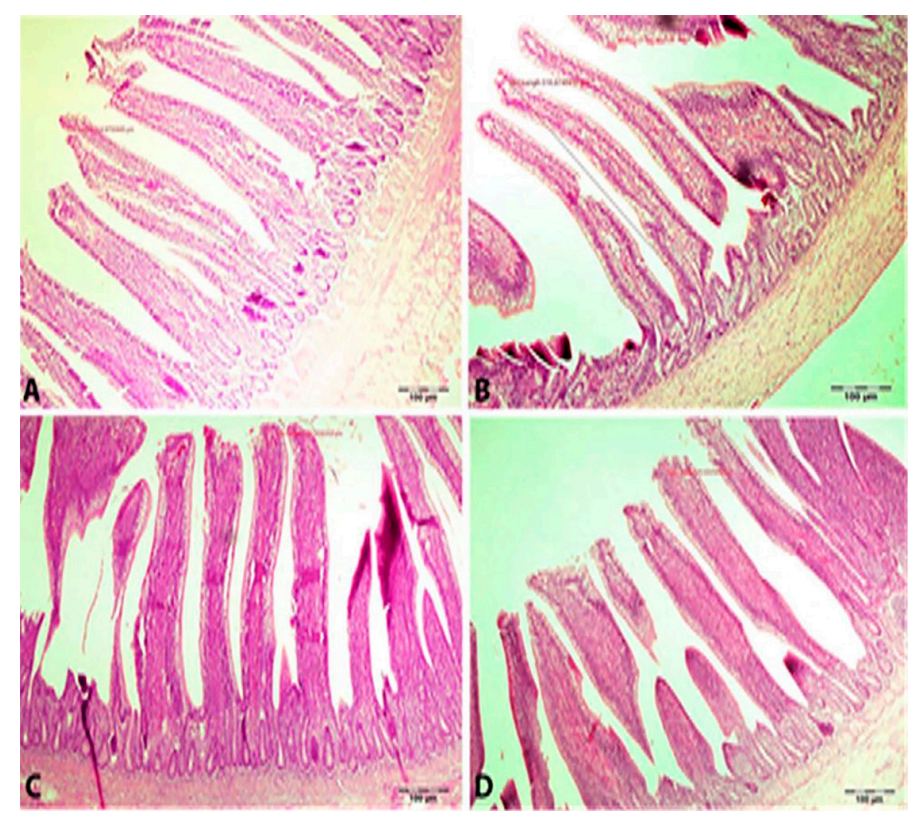

Figure 3. Control group (A); Jejunum tissues structure normal histological, Group T1 (B); Jejunum tissues structure normal histological, Group T2 (C); Jejunum tissues structure normal histological, Group T3 (D), Jejunum tissues structure normal histological, H\&E, Bar: $100 \mu \mathrm{m}$.

Furthermore, these results may have also been influenced by differences in the digestive speed and physical environment of the test subjects, as well as the climate conditions under which the tarragon was grown (Omer et al 2013).

The results of this study indicate that although the tarragon additive in the broiler diet did not have any effect on DFI and FCR values in the study for all periods, the tarragon additive decreased DWG on days 29-35 and 36-42 in the period studied $(P<0.05)$. Therefore, the tarragon additive had a negative effect on performance in these two periods. The tarragon additive did not alter the structure of the liver, kidney or intestinal tissues, but the longest bowel villus was in the T2 group. Adding different levels of tarragon powder to chicken feed appeared to produce different changes in the performance parameters of broiler chickens. Additional studies should be conducted to further confirm this relationship. 


\section{REFERENCES}

Aglarova AM, Zilfikarov IN, Severtseva OV. 2008. Biological characteristic and useful properties of tarragon (Artemisia dracunculus L.). Pharmaceut Chem J 42, 81-86.

Angas MR, Tabrizi HM, Amiri AS, Mozhdehi MM. 2015. The effect of tarragon extract on performance, carcass quality, hematologic parameters and microbial flora of intestinal contents in Japanese quail. Adv Appl Sci Res 6, 81-86.

Arabhosseini A, Huisman W, Van Boxtel A, Müller J. 2007. Long-term effects of drying conditions on the essential oil and color of tarragon leaves during storage. J Food Eng 79, 561-566.

Ariyadi B, Harimurti S. 2015. Effect of indigenous probiotics lactic acid bacteria on the small intestinal histology structure and the expression of mucins in the ileum of broiler chickens. Int J Poult Sci 14, 276-278.

Church DC, Pont WG. 1988. Basic Animal Nutrition and Feeding. $3^{\text {rd }}$ ed. Wiley Press, New York, USA.

Cross DE, Mcdevitt RM, Hillman K, Acamovic T. 2007. The effect of herbs and their associated essential oils on performance, dietary digestibility and gut microflora in chickens from 7 to 28 days of age. Br Poult Sci 48, 496-506.

Daly T, Jiwan MA, O'Brien NM, Aherne SA. 2010. Carotenoid content of commonly consumed herbs and assessment of their bioaccessibility using an in vitro digestion model. Plant Foods Hum Nutr 65, 164-169.

Dorman HJD, Deans SG. 2000. Antimicrobial agents from plants: antibacterial activity of plant volatile oils. J Appl Microbiol 88, 308-316.

Ebrahimi M. 2011. The effect of medicinal plants (cinnamon, red pepper, ginger and cumin) on performance of gastrointestinal, carcass characteristics and safety of broiler chickens fed with high levels of oil. Thesis, Islamic Azad University, Chalous, Iran.

Ebrahimi MA, Hoseini MH, Palizdar HR, Tabrizi M, Porelmi MR. 2013. Effect of cinnamon, red pepper, ginger and cumin on broilers performance. Res Opin Anim Vet Sci 3, 131-135.

Eidi A, Oryan S, Zaringhalam J, Rad M. 2015. Antinociceptive and anti-inflammatory effects of the aerial parts of Artemisia dracunculus in mice. Pharm Biol 54, 549-554.

Eisenman SW, Juliani HR, Struwe L, Simon JE. 2013. Essential oil diversity in North American wild tarragon (Artemisia dracunculus L.) with comparisons to French and Kyrgyz tarragon. Indust Crop Prod 49, 220-232.

Fonseca-García I, Escalera-Valente F, Martínez-González S, CarmonaGasca CA, Gutiérrez-Arenas DA, et al. 2017. Effect of oregano oil dietary supplementation on production parameters, height of intestinal villi and the antioxidant capacity in the breast of broiler. Austral J Vet Sci 49, 83-89.

Gharetappe FK, Hassanabadi A, Semnaninezhad H, Nassiry MR. 2015. The Effect of dietary tarragon (Artemisia dracunculus) and peppermint (Mentha piperita) laves on growth performance and antibody response of broiler chickens. Iran J Basic Med Sci 5, 403-409.

Hosseinzadeh Z, Farhoomand P, Najafi R. 2014. Effects of tarragon powders' different levels (Artemisia dracunculus) on performance and carcasses "characteristics male broiler chickens. Int J Adv Biol Biomed Res 2, 1750-1760.

Hosseinzadeh Z, Moghaddam G. 2014. Effects of tarragon powders' different levels (Artemisia dracunculus) on general performance and anetometric properties of digestive system of male broiler chickens. Int J Adv Biol Biomed Res 2, 1599-1605.

Incharoen T, Khambualai O, Yamauchi K. 2009. Performance and histological changes of the intestinal villi in chickens fed dietary natural zeolite including plant extract. Asian J Poult Sci 3, 42-50.

Incharoen T, Yamauchi K, Ericawa T. 2010. Histology of intestinal villi and epithelial cells in chickens fed low protein or low fat diets. Ital J Animal Sci 9, 429-434.

Jalilzadeh-Amin G, Maham M. 2015. The application of 1,8-cineole, a terpenoid oxide present in medicinal plants, inhibits castor oil-induced diarrhea in rats. Pharm Biol 53, 594-599.
Jalilzadeh-Amin G, Qarehdarvishlu BM. 2014. Effects of Artemisia dracunculus essential oil on diarrhea and intestinal transit time in rat gastrointestinal tract. Physiol Pharmacol 18, 416-428.

Karimi A, Hadian J, Farzaneh M, Khadivi-Khub A. 2015. Phenotypic diversity and volatile composition of Iranian Artemisia dracunculus. Indust Crop Prod 65, 315-323.

Kordali S, Cakir A, Mavi A, Kilic H, Yildirim A. 2005ª Screening of chemical composition and antifungal and antioxidant activities of the essential oils from three Turkish Artemisia species. J Agric Food Chem 53, 1408-1416.

Kordali S, Kotan R, Mavi A, Cakir A, Ala A, et al. 2005' . Determination of the chemical composition and antioxidant activity of the essential oil of Artemisia dracunculus and of the antifungal and antibacterial activities of Turkish Artemisia absinthium, A. dracunculus, Artemisia santonicum, and Artemisia spicigera essential oils. J Agric Food Chem 53, 9452-9458.

Kumlay AM, Yıldırım BA, Ekici K, Ercişli S. 2015. Screening biological activity of essential oils from Artemisia dracunculus L. Oxid Commun 3, 1320-1328.

Laudadio V, Passantino L, Perillo A, Lopresti G, Lopresti G, et al. 2012. Productive performance and histological features of intestinal mucosa of broiler chickens fed different dietary protein levels. Poul Sci 91, 265-270.

Lopes-Lutz D, Alviano DS, Alviano CS, Kolodziejczyk PP. 2008. Screening of chemical composition, antimicrobial and antioxidant activities of Artemisia essential oils. Phytochemistry 69, 1732-1738.

Meepagala KM, Sturtz G, Wedge DE. 2002. Antifungal constituents of the essential oil fraction of Artemisia dracunculus L. Var. dracunculus. J Agric Food Chem 50, 6989-6992.

Newman KE. 2002. Antibiotic resistance is a reality novel tecniques for overcoming antibiotic resistance when using new growht promoters. Proceedings of Alltech's 18 th Annual Symposium, Nottingham, UK, Pp 98-106.

Nurzy Ěska-Wierdak R, ZawiĞlak G. 2014. Herb yield and bioactıve compounds of tarragon (Artemisia dracunculus) as influenced by plant density. Acta Sci Pol 13, 207-221.

Obolskiy D, Pischel I, Feistel B, Glotov N, Heinrich M. 2011. Artemisia dracunculus $L$. (tarragon): A critical review of its traditional use, chemical composition, pharmacology, and safety. J Agric Food Chem 59, 11367-11384.

Olnood CG, Beski SSM, Lji PA, Choct M. 2015. Delivery routes for probiotics: effects on bird performance, intestinal morphology and gut microflora. Animal Nutrition 1, 192-202.

Omer EA, Abou Hussein EA, Hendawy SF, Ezz El-din Azza A, El Gendy AG. 2013. Effect of soil type and seasonal variation on growth, yield, essential oil and artemisinin content of Artemisa annиa L. International Research Journal of Horticulture 1, 15-27.

Pereira C, Barros L, Ferreira ICRF. 2015. A comparison of the nutritional contribution of thirty-nine aromatic plants used as condiments and/ or herbal infusions. Plant Foods Hum Nutr 70, 176-183.

Sen S, Ingale SL, Kim YW, Kim JS, Kim KH, et al. 2012. Effect of supplementation of Bacillus subtilis LS 1-2 to broiler diets on growth performance, nutrient retention, caecal microbiology and small intestinal morphology. Res Vet Sci 93, 264-268.

Tak I, Mohiuddin D, Ganai BA, Chishti MZ, Ahmad F, et al. 2014. Phytochemical studies on the extract and essential oils of Artemisia dracunculus L. (tarragon). Afr J Plant Sci 8, 72-75.

Uni Z, Ganot S, Sklan D. 1998. Posthatch development of mucosal function in the broiler small intestine. Poult Sci 77, 75-82.

Wang JX, Peng KM. 2008. Developmental morphology of the small intestine of african ostrich chicks. Poult Sci 87, 2629-2635.

Yavuz HM. 2001. Çiftlik hayvanlarının beslenmesinde temel prensipler ve karma yem üretiminde bazı bilimsel yaklaşımlar. Farmavet AŞ Yayinlari, Istanbul, Turkey.

Yildirim F, Tunç MA. 2018. The effect of dietary tarragon (Artemisia dracunculus) powders in different levels on carcass characteristics and some internal organ's weight of broiler chickens. Rev Bras Cienc Avic 20, 179-182. 